Research Article

\title{
Pattern of adverse drug reactions reported at a tertiary health care teaching hospital of Tripura: a retrospective study
}

\author{
Prithul Bhattacharjee*, Lakshman Das, Ranjib Ghosh, Lalromawii, Uttam Kumar Das
}

\begin{abstract}
Department of Pharmacology, Tripura Medical College and Dr. B. R. Ambedkar Memorial Teaching Hospital, Agartala, Tripura, India
\end{abstract}

Received: 14 June 2016 Accepted: 28 June 2016

*Correspondence to: Dr. Prithul Bhattacharjee, Email: drprithulb@gmail.com

Copyright: (C) the author(s), publisher and licensee Medip Academy. This is an openaccess article distributed under the terms of the Creative Commons Attribution NonCommercial License, which permits unrestricted noncommercial use, distribution, and reproduction in any medium, provided the original work is properly cited.

\begin{abstract}
Background: ADR monitoring and reporting activity is in its infancy in India. India rates below $1 \%$ in pharmacovigilance as against the world rate of $5 \%$. India is the fourth largest producer of pharmaceuticals in the world. So there is an immense need to improve the pharmacovigilance system to protect the Indian population. This study is aimed to identify ADRs and assess their pattern.

Methods: The reports of ADRs were recorded as per the standard guidelines fixed by pharmacovigilance programme of India (PvPI). Naranjo ADR probability scale was used to assess the causality of suspected ADRs. Severity of ADRs was identified using modified hartwig's criteria. Types of ADRs were identified using Rawlins and Thompson classification.

Results: A total 266 ADRs were reported from 190 patients. Majority of the ADRs were type A reactions. Highest incidence $(78.95 \%)$ of ADRs was observed between 12-59 years of age. $56.84 \%$ of patients were male and $43.16 \%$ were female. Majority of the patients were suffering from single disease and receiving less than six medications. In the assessment of severity mild, moderate and severe ADRs were $57.89 \%, 35.26 \%$ and $6.84 \%$ respectively. In causality assessment $3.16 \%$ cases were unlikely, $57.37 \%$ cases were possible, $38.95 \%$ cases were probable and $0.52 \%$ cases were certain.

Conclusions: The present study shows ADRs are commonly encountered at this tertiary health care set up. Many ADRs are life threatening type B reactions, but the higher incidence of type A reactions means that these can be avoided.
\end{abstract}

Keywords: Patient safety, Pharmacovigilance, Causality, Retrospective study

\section{INTRODUCTION}

Adverse drug reactions (ADRs) are a major cause of morbidity. ADRs related hospitalizations have consistently increased which has caused an economic burden to the developing countries like India. ${ }^{1}$ In USA, ADRs are responsible for 3.4-7.0\% of hospital admissions. ${ }^{2}$ Studies from overseas as well as India have demonstrated that polypharmacy is associated with increased potential for ADRs. ${ }^{3}$

ADR monitoring and reporting activity is in its infancy in India. India rates below $1 \%$ in pharmacovigilance as against the world rate of $5 \%{ }^{4}$ India is the fourth largest producer of pharmaceuticals in the world. There are more than 6000 licensed drug manufacturers and more than
60,000 branded formulations. ${ }^{5}$ India is also emerging as a clinical trials hub. Many new drugs are being introduced in the country and so there is an immense need to improve the pharmacovigilance system to protect the Indian population from potential harm that may be caused by some of the drugs. The important reason of less pharmacovigilance activity is lack of awareness and lack of interest of health care professionals in ADR reporting and documentation. ${ }^{6}$ Therefore, this study is aimed to identify ADRs and assess their pattern.

\section{METHODS}

A retrospective data analysis was carried out at Tripura Medical College and Dr. BRAM Teaching Hospital (TMC) in last 18 months (January 2014 to June 2015) 
from different departments. All the "suspected ADR reporting forms" of Indian Pharmacopoeia Commission (IPC) were filled up by health care professionals in both outpatients departments (OPD) and in patients departments (IPD). For each patient the form was completed with regard to

- Age of the patient,

- Gender of the patient,

- Number of $\operatorname{drug}(\mathrm{s})$ prescribed,

- Duration of treatment (days).

- Number of ailment(s), the patient was suffering from,

- $\quad$ Causality of the ADR(s),

- $\quad$ Severity of the identified ADR(s),

- $\quad$ Type of ADR(s).

The causality assessment of the ADRs was done using Naranjo ADR probability scale. ${ }^{7}$ Scoring of the suspected ADRs was done by using a set of questions of Naranjo's algorithm. Score of $>9$ were graded as definite, score 5-8 as probable, score 1-4 as possible and score 0 as doubtful. Severity of the identified ADRs was assessed at different levels, ranging between 1 and 7 using modified Hartwig's criteria. ${ }^{8}$ Mild ADRs belonged to levels 1 and 2, moderate ADRs belonged to level 3 and 4 and severe ADRs were level 5 and above. Types of ADRs were identified using Rawlins and Thompson classification. ${ }^{9}$

Study was conducted after obtaining ethical approval from the Institutional Ethical Committee of TMC, Agartala, Tripura, India.

\section{Statistical analysis}

Profile of patients like age, gender, number of ailments, number of drugs prescribed, duration of treatment, the responsible drug(s) for ADRs with causality assessment, severity of the identified ADRs and type of ADRs are represented as percentage. Odds ratio was calculated to assess the relationship between the profile of patient and the common system wise ADRs. Statistical significance was determined at $95 \%$ level of confidence.

\section{RESULTS}

Types of ADRs with their numbers and suspected drug/drugs are shown in Table 1. Total 266 ADRs were reported from 190 patients. Out of 266 ADRs, the most commonly identified ADRs were related to gastrointestinal system disorders $(30.82 \%)$, followed by skin and appendages disorders (29.69\%).

Table 1: Types of ADRs with their numbers $(\mathrm{N}=266)$ and suspected drug/drugs.

\begin{tabular}{|c|c|c|}
\hline Reaction/Event & No & Drugs involved \\
\hline \multicolumn{3}{|c|}{ Skin and appendages disorder- $\mathrm{N}=79(29.69 \%)$} \\
\hline Urticaria & 4 & $\begin{array}{l}\text { Norfloxacin, japanese encephalitis vaccine, piperacillin+tazobactum, } \\
\text { trypsin+diclofenac+serratiopeptidase, }\end{array}$ \\
\hline $\begin{array}{l}\text { Steven-Johnson } \\
\text { syndrome }\end{array}$ & 8 & $\begin{array}{l}\text { Sulphasalazine, norfloxacin(2), co-trimoxazole, paracetamol(2) phenytoin, } \\
\text { ofloxacin+ornidazole. }\end{array}$ \\
\hline Maculopapular rash & 11 & $\begin{array}{l}\text { Spiramycin, rifaximine, inh+ ethambutol+streptomycin, ceftriaxone }+ \\
\text { tazobactum, ceftriaxone, ertapenem, dehydroepiandrosterone, } \\
\text { cefpodoxime+ofloxacin, lamotrigine, azithromycin, ursedeoxycholic acid, s- } \\
\text { adenosyl methionine. }\end{array}$ \\
\hline Fixed drug eruption & 13 & $\begin{array}{l}\text { Ofloxacin }+ \text { ornidazole }(4) \text {, ornidazole, norfloxacin, pain-nil(ayurvedic), } \\
\text { paracetamol, fluconazole, norfloxacin+tinidazole( } 2 \text { ), diclofenac, ketorolac. }\end{array}$ \\
\hline Angioedema & 2 & Norfloxacin, trypsin+diclofenac+serratiopeptidase, \\
\hline Generalised itching & 16 & $\begin{array}{l}\text { Ofloxacin+ornidazole( } 2 \text { ), cefoperazone+sulbactum(3), amoxycillin+clavulanic } \\
\text { acid, rabeprazole, cefotaxime, ceftriaxone (3), ofloxacin, amikacin( } 2 \text {, } \\
\text { clindamycin, rifampicin. }\end{array}$ \\
\hline Blister & 2 & Spiramycin, vancomycin \\
\hline $\begin{array}{l}\text { Skin } \\
\text { hyperpigmentation }\end{array}$ & 3 & Amlodipine+atenolol(2), isoniazid, rifampicin , pyrazinamide, ethambutol \\
\hline $\begin{array}{l}\text { Positive Skin } \\
\text { Hypersensitivity Test }\end{array}$ & 20 & $\begin{array}{l}\text { amoxycillin+clavulanic acid( } 3) \text {, ceftriaxone }(5) \text {, ceftriaxone+tazobactum, } \\
\text { ceftriaxone+salbactum, azithromycin, cefoperazone+sulbactum( } 2) \text {, } \\
\text { cefuroxime( } 2) \text {, cefotaxime+salbactum, piperacillin }+\operatorname{tazobactum}(2) \text {, ofloxacin, } \\
\text { moxifloxacin. }\end{array}$ \\
\hline \multicolumn{3}{|c|}{ Gastro-intestinal system disorders- $\mathrm{N}=82(30.82 \%)$} \\
\hline Nausea, & 15 & $\begin{array}{l}\text { INH+rifampicin+ethambutol+pyrazinamide+streptomycin, } \\
\text { INH+rifampicin+ethambutol+pyrazinamide, pregabalin+Vit B-12, cefoperazone, } \\
\text { cefuroxime(2), amoxycillin+clavulanic acid, Japanese encephalitis vaccine(2), } \\
\text { ceftriaxone, cisplatin+paclitaxel+fluorouracil, amikacin, cisplatin, imipenem, } \\
\text { satronidazole+ofloxacin }\end{array}$ \\
\hline Vomiting & 32 & Lithium, INH+rifampicin+ethambutol+pyrazinamide(6), \\
\hline
\end{tabular}




\begin{tabular}{|c|c|c|}
\hline & & $\begin{array}{l}\text { INH+rifampicin+ethambutol+pyrazinamide+streptomycin(2), INH+ethambutol, } \\
\text { INH+rifampicin, carboprost, ertapenam, ceftriaxone(3),cefuroxime, } \\
\text { ceftriaxone+tazobactum, cefoperazone+salbactum(2), Japanese encephalitis } \\
\text { vaccine(7), paclitexal, +carboplatin, cyclophosphomide+epirubicin+flurouracil, } \\
\text { methylcobolamin, imipenem, amikacin, dextrose. }\end{array}$ \\
\hline Loose stool & 10 & $\begin{array}{l}\text { Clindamycin, amoxycillin+clavulanic acid, ceftriaxone, Japanese encephalitis } \\
\text { vaccine(4), fluoxetine, INH+ethambutol, terbinafine. }\end{array}$ \\
\hline Pain abdomen & 8 & Co-tromoxazole, Japanese encephalitis vaccine(7) \\
\hline Constipation & 2 & Prothiaden, Japanese encephalitis vaccine, \\
\hline Metallic taste & 1 & Satrnidazole+ofloxacin \\
\hline Decreased appetite & 4 & $\begin{array}{l}\text { Cisplatin+paclitaxel+fluorouracil, cisplatin, paclitaxel+carboplatin, } \\
\text { cyclophosphomide+epirubicin+flurouracil, }\end{array}$ \\
\hline Dysphagia & 3 & Cefuroxime, multivitamin, cisplatin \\
\hline Malena & 1 & Ibuprofen+paracetamol \\
\hline Hepatitis & 5 & Streptomyci+ethambutol, INH+rifampicin+ethambutol+pyrazinamide(4) \\
\hline Hepatic failure & 1 & Nimesulide+paracetamol \\
\hline \multicolumn{3}{|c|}{ Central and peripheral nervous system disorders- $\mathrm{N}=35(13.15 \%)$} \\
\hline Psychosis & 1 & Imipenam+cilastatin \\
\hline Nightmares & 1 & Mirtazepine \\
\hline Headache, & 6 & $\begin{array}{l}\text { Etodolac+ paracetamol, satronidazole+ofloxacin, Pregabalin+methylcobalamin, } \\
\text { Japanese encephalitis vaccine, amikacin, ceftriaxone. }\end{array}$ \\
\hline Ringing in ears & 1 & Etodolac+ paracetamol \\
\hline Dizziness & 3 & INH+rifampicin+ethambutol+pyrazinamide, Ceftriaxone(2) \\
\hline Numbness & 3 & Lignocaine +adrenaline, Pregabalin+methylcobalamin \\
\hline Akathisia & 4 & Olanzepine, amisulpride, iloperidone, quetiapine \\
\hline Convulsion & 5 & Ertapenem, Japanese encephalitis vaccine(4) \\
\hline Tremor & 1 & Haloperidol \\
\hline Dystonia & 2 & Risperidone, haloperidol \\
\hline $\begin{array}{l}\text { Extrapyramidal } \\
\text { Syndrome }\end{array}$ & 7 & Haloperidol(2), aripiprazole, amisulpride(2), olanzapine, risperidone \\
\hline $\begin{array}{l}\text { Sluggishness of } \\
\text { movements }\end{array}$ & 1 & Risperidone \\
\hline \multicolumn{3}{|c|}{ Muskulo-skeletal system disorder- $\mathrm{N}=4(1.50 \%)$} \\
\hline Joint pain & 1 & INH+rifampicin+ethambutol+pyrazinamide, \\
\hline Myopathy & 1 & Fenofibrate + pitavastatin, \\
\hline Leg pain & 2 & Cyclophosphomide+epirubicin+flurouracil, promethazine \\
\hline \multicolumn{3}{|c|}{ Cardiovascular disorders- $\mathrm{N}=3(1.13 \%)$} \\
\hline Hypotension & 2 & Hydrxyethyl starch, netilmicin \\
\hline Bradycardia & 1 & Hydrxyethyl starch \\
\hline \multicolumn{3}{|l|}{ Eye disorders-1(0.38) } \\
\hline $\begin{array}{l}\text { Conjunctival } \\
\text { hemorrhage }\end{array}$ & 1 & Vitamin B complex \\
\hline \multicolumn{3}{|c|}{ Body as a whole-general disorders- $\mathrm{N}=42(15.78 \%)$} \\
\hline Syncope & 1 & Iron sucrose \\
\hline Chest pain & 1 & Mitrazepine \\
\hline Chest tightness & 1 & Dextrose \\
\hline Burning sensation & 2 & Iron sucrose, dextrose \\
\hline Oedema legs & 8 & $\begin{array}{l}\text { Aceclofenac+paracetamol+seratiopeptidase, } \\
\text { Aceclofenac+paracetamol+rabeprazole (2), s-amlodipine+telmisartan (2), s- } \\
\text { amlodipine+atenolol, amlodipine, acetaminophen+tramadol. }\end{array}$ \\
\hline Oedema generalised & 5 & Piroxicum, rifaximine, diclofenac, cefuroxime, multivitamin \\
\hline Fever & 19 & Rifaximine, Japanese encephalitis vaccine (18) \\
\hline Generalised weakness & 1 & $\begin{array}{l}\text { INH+rifampicin+ethambutol+pyrazinamide+streptomycin, } \\
\text { cyclophosphomide+epirubicin+flurouracil }\end{array}$ \\
\hline Increased salivation & 1 & Haloperidol \\
\hline Discomfort in throat & 2 & Cefoperazone+salbactum, chlorpromazine+ trihexyphenidyl \\
\hline
\end{tabular}




\begin{tabular}{|lcl|}
\hline \multicolumn{3}{|l|}{ Urinary system disorder- $\mathbf{N = 2}(\mathbf{0 . 7 5 \%})$} \\
\hline Urinary retention & 2 & Haloperidol, nortryptline hydrochloride \\
\hline Endocrine disorders- $\mathbf{N}=\mathbf{2}(\mathbf{0 . 7 5} \%)$ & \\
\hline Diabetes mellitus & 1 & Aripiprazole \\
\hline Galactorrhoea & 1 & Levosulpiride \\
\hline Respiratory system disorder- $\mathbf{N = 9 ( 3 . 3 8 \% )}$ \\
\hline Dyspnea & 4 & Haloperidol, misoprostol, olanzapine, amikacin \\
\hline Throat pain & 2 & Ofloxacin + ornidazole, etodolac+paracetamol \\
\hline Cough and cold & 3 & Japanese encephalitis vaccine \\
\hline Others- N=6 (2.26\%) & & \\
\hline Sweating & 1 & Misopristol \\
\hline Palpitation & 1 & Misopristol \\
\hline Periorbital edema & 1 & Misopristol \\
\hline Shievering & 1 & Iron sucrose(2), cefuroxime \\
\hline Hypoxia & 1 & Hydrxyethyl starch \\
\hline Frothing from mouth & 1 & Hydrxyethyl starch \\
\hline Death & 1 & Japanese encephalitis vaccine \\
\hline
\end{tabular}

Figures in parenthesis against the name of the drug indicate the frequency of occurrence of each reaction by the concerned drug.

The ADRs related to body as whole-general disorders were $15.78 \%$ and central and peripheral nervous system disorders were $13.15 \%$. ADRs related to other systems (musculo-skeletal system disorders, cardiovascular disorders, eye disorders, urinary system disorders, respiratory system disorders) were $10.56 \%$. Out of all ADRs $71.43 \%$ was type-A reactions while $28.57 \%$ was type-B reactions.

Profile of patients suffering from ADRs $(\mathrm{N}=190)$ is shown in Table 2 and determinants of various types of ADRs among study subjects are shown in Table 3. Out of 190 patients, majority of the patients $(78.95 \%)$ were between 12-59 years. The association of skin and appendages disorders, gastrointestinal disorders and general body disorders was more common in the age group of $12-59$ years $(\mathrm{p}<0.001)$.

There was preponderance of ADRs in males as compared to females $(56.84 \%$ vs $43.16 \%)$. The association of females in developing general body disorders was found statistically significant $(\mathrm{p}=0.006) .84 .74 \%$ patients were receiving less than 6 medications while $15.26 \%$ were receiving more than 6 medications.

It was found that $90.53 \%$ patients were suffering from only single disease and $9.47 \%$ patients were suffering from more than one disease. $79.48 \%$ patients developed ADRs within 10 days of treatment while $20.52 \%$ patients developed ADRs after 10 days of treatment.

The development of skin and appendages related and central and peripheral nervous systems related ADRs were more common $(p<0.05)$ in the group of patients receiving treatment for more than 10 days. When analyzed on Naranjo ADR probability scale, $3.16 \%$ ADRs were unlikely (score 0), 57.37\% ADRs were possible (score 0-4), 38.95\% ADRs were probable (score 5-8) and $0.52 \%$ ADRs were certain (score >9). The association of the skin and appendages related ADRs with the causality scoring of 0-4 was highly significant $(\mathrm{p}=0.001)$. Based on modified Hartwig severity scale, $57.89 \%$ reactions were mild, $35.26 \%$ were moderate and $6.84 \%$ were severe. The mild reactions were more common in skin and appendages related ADRs $(\mathrm{p}=0.002)$.

\section{Table 2: Profile of patients suffering from ADRs} $(\mathrm{N}=190)$.

\begin{tabular}{|c|c|c|}
\hline Characteristics & & $\mathbf{N}(\%)$ \\
\hline \multirow{3}{*}{ Age (in years) } & $<12$ & $22(11.58)$ \\
\hline & $12-59$ & $150(78.95)$ \\
\hline & $60-75$ & $18(9.48)$ \\
\hline \multirow[t]{2}{*}{ Gender } & Male & $108(56.84)$ \\
\hline & Female & $82(43.16)$ \\
\hline \multirow{3}{*}{$\begin{array}{l}\text { Number of } \\
\text { medication(s) }\end{array}$} & $<6$ & $161(84.74)$ \\
\hline & $6-10$ & $27(14.21)$ \\
\hline & $>10$ & $2(1.05)$ \\
\hline \multirow{2}{*}{$\begin{array}{l}\text { Duration of treatment } \\
\text { (in days) }\end{array}$} & $<10$ & $151(79.48)$ \\
\hline & $>10$ & $39(20.52)$ \\
\hline \multirow{3}{*}{ Number of diagnosis } & Single & $172(90.53)$ \\
\hline & Double & $16(8.42)$ \\
\hline & Multiple & $2(1.05)$ \\
\hline \multirow{4}{*}{ Causality } & Unlikely & $6(3.16)$ \\
\hline & Possible & $109(57.37)$ \\
\hline & Probable & $74(38.95)$ \\
\hline & Certain & $1(0.52)$ \\
\hline \multirow{3}{*}{ Severity of ADRs } & Mild & $110(57.89)$ \\
\hline & Moderate & $67(35.26)$ \\
\hline & Severe & $13(6.84)$ \\
\hline \multirow{2}{*}{ Type of ADRs } & Type A & $190(71.43)$ \\
\hline & Type B & $76(28.57)$ \\
\hline
\end{tabular}




\section{Table 3: Determinants of various types of ADRs among study subjects.}

\begin{tabular}{|c|c|c|c|c|c|c|c|c|c|c|c|c|}
\hline \multirow{2}{*}{\multicolumn{2}{|c|}{ Characteristics }} & \multirow[b]{2}{*}{ Total } & \multicolumn{10}{|c|}{ Types of ADRs ( $\mathrm{N}=266)$} \\
\hline & & & $\begin{array}{l}\text { Skin and } \\
\text { app } \\
(\mathrm{N}=79)\end{array}$ & $\begin{array}{l}\text { OR } \\
(\mathrm{p} \\
\text { value })\end{array}$ & $\begin{array}{l}\text { GI disorder } \\
(\mathrm{N}=82)\end{array}$ & $\begin{array}{l}\text { OR } \\
(\mathrm{p} \\
\text { value })\end{array}$ & $\begin{array}{l}\text { General } \\
(\mathrm{N}=42)\end{array}$ & $\begin{array}{l}\text { OR } \\
(\mathrm{p} \\
\text { value })\end{array}$ & $\begin{array}{l}\text { CNS and } \\
\text { PNS } \\
(\mathrm{N}=35)\end{array}$ & $\begin{array}{l}\text { OR } \\
(\mathrm{p} \\
\text { value })\end{array}$ & $\begin{array}{l}\text { Others } \\
(\mathrm{N}=28)\end{array}$ & $\begin{array}{l}\text { OR } \\
(\mathrm{p} \\
\text { value })\end{array}$ \\
\hline \multirow{2}{*}{$\begin{array}{l}\text { Age } \\
\text { (in years) }\end{array}$} & $12-59$ & 150 & $72(91.13)$ & 4.34 & $53(64.63)$ & 0.21 & $17(40.47)$ & 0.08 & $27(77.14)$ & 0.88 & $20(71.42)$ & 0.62 \\
\hline & $<12$ and $\geq 60$ & 40 & $7(8.87)$ & $(<0.001)$ & $29(35.37)$ & $(<0.001)$ & $25(59.53)$ & $(<0.001)$ & $8(22.86)$ & $(0.772)$ & $8(28.58)$ & $(0.291)$ \\
\hline \multirow{2}{*}{ Gender } & Male & 108 & $51(64.55)$ & 1.73 & $48(58.53)$ & 1.13 & $16(38)$ & 0.37 & $16(45.72)$ & 0.58 & $15(53.58)$ & 0.86 \\
\hline & Female & 82 & $28(35.45)$ & $(0.070)$ & $34(41.47)$ & $(0.681)$ & $26(62)$ & $(0.006)$ & $19(54.28)$ & $(0.141)$ & $13(46.42)$ & $(0.705)$ \\
\hline \multirow{2}{*}{$\begin{array}{l}\text { No. of } \\
\text { medications }\end{array}$} & $<6$ & 161 & $71(89.88)$ & 2.07 & $70(85.37)$ & 1.09 & $39(92.86)$ & 2.77 & $29(82.85)$ & 0.84 & $28(100)$ & - \\
\hline & $>6$ & 29 & $8(10.12)$ & $(0.097)$ & $12(14.63)$ & $(0.834)$ & $3(7.14)$ & $(0.097)$ & $6(17.15)$ & $(0.732)$ & - & $(0.015)$ \\
\hline \multirow{2}{*}{$\begin{array}{l}\text { Duration of } \\
T / t \text { (in days) }\end{array}$} & $<10$ & 151 & $70(88.60)$ & 2.88 & $68(82.93)$ & 1.46 & $35(83.34)$ & 1.38 & $22(62.86)$ & 0.34 & $20(71.83)$ & 0.59 \\
\hline & $>10$ & 39 & $9(11.40)$ & $(0.009)$ & $14(17.07)$ & $(0.305)$ & $7(16.66)$ & $(0.483)$ & $13(37.14)$ & $(0.007)$ & $8(28.57)$ & $(0.254)$ \\
\hline \multirow{2}{*}{ Causality } & Score $0-4$ & 115 & $37(46.84)$ & 0.37 & $52(63.42)$ & 1.24 & $26(61.90)$ & 1.08 & $20(57.15)$ & 0.84 & $20(71.83)$ & 1.76 \\
\hline & Score 5-9 & 75 & $42(53.16)$ & $(0.001)$ & $30(36.58)$ & $(0.478)$ & $16(38.10)$ & $(0.836)$ & $15(42.85)$ & $(0.650)$ & $8(28.57)$ & $(0.201)$ \\
\hline \multirow{2}{*}{ Severity } & Mild & 110 & $56(70.88)$ & 2.57 & $50(60.98)$ & 1.25 & $23(54.76)$ & 0.85 & $21(60)$ & 1.11 & $17(60.72)$ & 0.47 \\
\hline & $\begin{array}{l}\text { Mod and } \\
\text { severe }\end{array}$ & 80 & $23(29.12)$ & $(0.002)$ & $32(39.02)$ & $(0.454)$ & $19(45.24)$ & $(0.641)$ & $14(40)$ & $(0.780)$ & $11(39.28)$ & $(0.744)$ \\
\hline
\end{tabular}




\section{DISCUSSION}

ADRs are distressing to both the patients and physicians. Severe ADRs may lead to mortality, but even without this, there may be prolongation of hospital stay and increase in the cost of the treatment.

The reported 266 ADRs were categorized by Rawlins and Thompson classification and correlation of various types of ADRs among study subjects were established. In the present study, gastrointestinal system related ADRs were the highest $(30.82 \%)$. Gor AP et al in their study also demonstrated highest incidence $(66.67 \%)$ of ADRs related to gastrointestinal system. ${ }^{10}$ The occurrence of high incidence of ADRs related to gastrointestinal system in the age group of $12-59$ years $(64.63 \%)$ was statistically highly significant $(\mathrm{p}<0.001)$. Next system involved was skin and appendages disorders $(29.70 \%)$. Saha A. et al demonstrated that the incidence of Stevens Johnson syndrome Toxic epidermal necrolysis and overlap of two was $24.50 \% .^{11}$ In the present study, $10.13 \%$ ADRs of skin and appendage disorders were life threatening Stevens Johnson syndrome. The correlations of high incidence of skin and appendages related ADRs in 12-59 years of age group $(91.13 \%)$, duration of treatment less than 10 days $(88.60 \%)$, causality score of 5-9 $(53.16 \%)$ and severity of mild type $(70.88 \%)$ were statistically significant. The remaining systems affected were body as whole-general disorders $(15.79 \%)$, central and peripheral nervous system disorders (13.16\%) and other systems (10.52\%).

In contrast to ADRs related to other systems in this study, higher incidence of ADRs related to body as a wholegeneral disorders were observed in the age group of $<12$ years and $\geq 60$ years $(59.53 \%)$ and this correlation was statistically highly significant $(\mathrm{p}<0.001)$. Higher incidence of ADRs related to body as whole-general disorders were also observed in female patients $(62 \%)$ and this relationship was also statistically significant $(\mathrm{p}=0.006)$. Central and peripheral nervous systems related ADRs were significantly $(\mathrm{p}=0.007)$ associated with the treatment of less than 10 days duration. $71.43 \%$ ADRs belong to type A (augmented) reactions. As such, out of all ADRs, $80 \%$ of the reactions are of type A12 and hence our finding is not surprising.

Profile of the patients like age, gender, number of medications, duration of treatment and number of diagnosis were also assessed. Age is an important risk factor for ADRs and incidence of ADRs increases in elderly patients. Mahesh NB et al reported the proportion of patients aged $<18,18-65$ and $>65$ years were $15.5 \%$, $80.1 \%$, and $4.4 \%$, respectively. ${ }^{13}$ In this study, majority of ADRs $(78.95 \%)$ were observed in the age group between 12-59 years. Some studies have reported a higher incidence of ADRs in females. ${ }^{14}$ Gor AP et al reported that there was no influence of sex on the occurrence rate of ADRs. ${ }^{10}$ In this study higher incidence is seen in males $(56.84 \%)$ in comparison to females $(43.16 \%)$. It is a wellestablished fact that as the number of drugs increases, the chance of developing ADR also increases. ${ }^{10}$ The present study reveals that $84.74 \%$ patient were receiving less than 6 medications while $15.26 \%$ were receiving more than 6 medications. It was found that $90.53 \%$ patients were suffering from only single disease and $9.47 \%$ patients were suffering from more than one disease. These findings do not correlate with the findings of the previous studies. ${ }^{10}$ However; this may be due to pattern of adverse drug reporting system which may vary from place to place. Earlier studies have documented, most of the ADRs develop within the first 10 days of administering the drug. ${ }^{15}$ In the present study, $79.48 \%$ patients developed ADRs within 10 days of treatment while $20.52 \%$ patients developed ADRs after 10 days of treatment. This emphasizes the need of observing the patients closely in the initial period of treatment. The results of this study showed that the most common causality category using the Naranjo algorithm was possible (57.37\%) which substantiates the findings of Macedo et al and Lei et al. ${ }^{16,17}$ Most of the ADRs were mild (57.89\%), followed by moderate $(35.26 \%)$ and severe $(6.84 \%)$.

\section{CONCLUSION}

This study shows ADRs are very common in this tertiary health care teaching hospital. Most of these ADRs are preventable as there is higher incidence of type A reactions. Although the present study has some limitations as it is a retrospective analytical study, still this study would definitely give an insight into the pattern of ADRs in a tertiary health care centre and may help to increase awareness for further pharmacovigilance studies.

\section{ACKNOWLEDGEMENTS}

Authors would like to acknowledge IPC, Ghaziabad, New Delhi for the support to the ADR monitoring centre, TMC, Agartala, Tripura India. Authors are also grateful to the Principal, Tripura Medical College and Dr. B.R. Ambedkar Memorial Teaching Hospital, Agartala, Tripura for providing the necessary facilities to carry out this study.

\section{Funding: No funding sources}

Conflict of interest: None declared

Ethical approval: The study was approved by the Institutional Ethics Committee

\section{REFERENCES}

1. Zhang M, Holman CDJ, Preen DB, Brameld K. Repeat adverse drug reactions causing hospitalization in older Australians: a populationbased longitudinal study 1980-2003. Br J Clin Pharmacol. 2007;63:163-70.

2. Davies EC, Green CF, Taylor S, Williamson PR, Mottram DR, Pirmohamed M. Adverse drug reactions in hospital in-patients: a prospective analysis of 3695 patient-episodes. PLoS ONE. 2009;4:e4439. 
3. Kaur S, Kapoor V, Mahajan R, Lal M. Monitoring of incidence, severity and causality of adverse drug reactions in hospitalized patients with cardiovascular diseases. Indian J Pharmacol. 2011;43(1):22-6.

4. Prakash S. Pharmacovigilance in India. Indian J Pharmacol. 2007;39:123.

5. Biswas P, Biswas AK. Setting standards for proactive pharmacovigilance in India: The way forward. Indian J Pharmacol. 2007;39:124-8.

6. Jose J, Rao PG. Pattern of adverse drug reactions notified by spontaneous reporting in an Indian tertiary care teaching hospital. Pharmacol Res. 2006;54:226-33.

7. Naranjo CA, Busto U, Sellers EM, Sandor P, Ruiz I, Roberts EA et al. A method for estimating the probability of adverse drug reactions. Clin Pharmacol Ther. 1981;30:239-45.

8. Rawlins MD, Thompson JW. Pathogenesis of adverse drug reactions. In: Davies DM, ed Textbook of adverse drug reactions. 10 ${ }^{\text {th }}$. Oxford:Oxford University Press;1977:27.

9. Hartwig SC, Siegel J, Schneider PJ. Preventability and severity assessment in reporting adverse drug reactions. Am J Hosp Pharm. 1992;49:2229-32.

10. Gor AP, Desai SV. Adverse drug reactions (ADR) in the inpatients of medicine department of a rural tertiary care teaching hospital and influence of pharmacovigilance in reporting ADR. Indian $\mathbf{J}$ Pharmacol. 2008;40(1):37-40.

11. Saha A, Das NK, Hazra A, Gharami RC, Chowdhury SN, Datta PK. Cutaneous adverse drug reaction profile in a tertiary care outpatient setting in Eastern India. Indian J Pharmacol. 2012;44(6):7927.

12. Laurence DR, Bennett PN, Brown MJ. Unwanted effects and adverse drug reactions. In: Clinical Pharmacology. 9th ed. New Delhi, India: Elsevier; 2006:135-150.

13. Belhekar MN, Taur SR, Munshi RP. A study of agreement between the naranjo algorithm and WHOUMC criteria for causality assessment of adverse drug reactions. Indian J Pharmacol. 2014;46(1):11720.

14. Schwartz JB. The influence of sex on pharmacokinetics. Clin Pharmaco. 2003;42:107-21.

15. Eileen G, Hollcend, Phevm D, Frank V. Degrig M.D. Drug induced disorder D. family Physician November 1997;2:10.

16. Macedo AF, Marques FB, Ribeiro CF, Teixeira F. Causality assessment of adverse drug reactions: comparison of the results obtained from published decisional algorithms and from the evaluations of an expert panel. Pharmacoepidemiol Drug Saf. 2005; 14:885-90.

17. Lei HS, Rahman AF, Haq AS. Adverse drug reaction reports in Malaysia: comparison of causality assessments. Malays J Pharm Sci. 2007;5:7-17.

Cite this article as: Bhattacharjee $\mathrm{P}$, Das L, Ghosh R, Lalromawii, Das UK. Pattern of adverse drug reactions reported at a tertiary health care teaching hospital of Tripura: a retrospective study. Int J Basic Clin Pharmacol 2016;5:1293-9. 